\title{
Evaluation of PEMFC power systems for UPS base station applications ${ }^{\text {th }}$
}

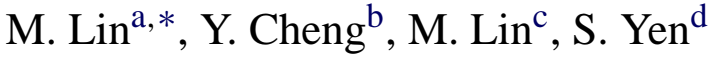 \\ a Tatung Company/System Technologies Inc., Taipei, Taiwan \\ b Taiwan Insitute of Economic Research, Taipei, Taiwan \\ c Acbel Polytech Inc., Taipei, Taiwan \\ d National Taiwan University, Taipei, Taiwan
}

Received 1 August 2004; accepted 20 August 2004

\begin{abstract}
For UPS applications such as the mobile phone base station, the selection of PEM fuel cell technology seems only feasible for the case of a heavy-duty service time requirement. The weight reduction of the whole energy system using fuel cell technology is significant, and the volume and the cost can also be superior when the service time is over $24 \mathrm{~h}$. If the production cost and the module volume of fuel cell system can be further reduced, the results will be more promising.
\end{abstract}

(C) 2004 Published by Elsevier B.V.

Keywords: PEMFC; UPS applications; Base station

\section{Introduction}

The commercial progress of fuel cell technologies is approaching a critical point, and lots of developers are eager to look for the initial niche market. One of uses may be the application to UPS such as a mobile phone base station [1,2]. According to the present situation in Taiwan, there are over 25,000 base stations constructed by six local telecom companies. Due to typhoons, earthquakes, and floods which frequently happen in Taiwan, interruptions of electricity supply are a severe threat to uninterrupted service of mobile phones. Telecom companies usually use lead-acid batteries to extend service time during blackout periods. However, some limitations of volume, weight, and cost are considered for this UPS application. Apparently, it would not be practical to extend the UPS service time from currently 2 or $4 \mathrm{~h}$ to $8 \mathrm{~h}$, or even

\footnotetext{
is Presented at 2004 Fuel Cell Seminar, San Antonio, TX, USA, 1-5 November, 2004.

* Corresponding author. Tel.: +886 $225925252 \times 2647$; fax: +886225948201 .

E-mail address: m.h.lin@tatung.com (M. Lin).
}

$24 \mathrm{~h}$. Thus, PEMFC power generators may be an interesting option for heavy-duty UPS applications.

In order to understand the effects of device cost, module weight, module volume and energy expense, comparisons and analysis of conventional lead-acid battery units and proposed PEMFC power generating systems for the UPS application in the case of base station has been illustrated and evaluated in this study.

\section{System descriptions and data collection}

A standard online energy system used in the mobile phone base station consists of switching mold rectifiers, control and supervisory module, ac and dc power distribution units, battery management, and low voltage disconnect switch options $[3,4]$. As shown in Fig. 1(a), a conventional model adopts lead-acid battery packs for supplying electricity during a blackout period. If the runtime of a base station needs to be extended, then the battery system should be enlarged. In the proposed fuel cell model as depicted in Fig. 1(b), a PEMFC 

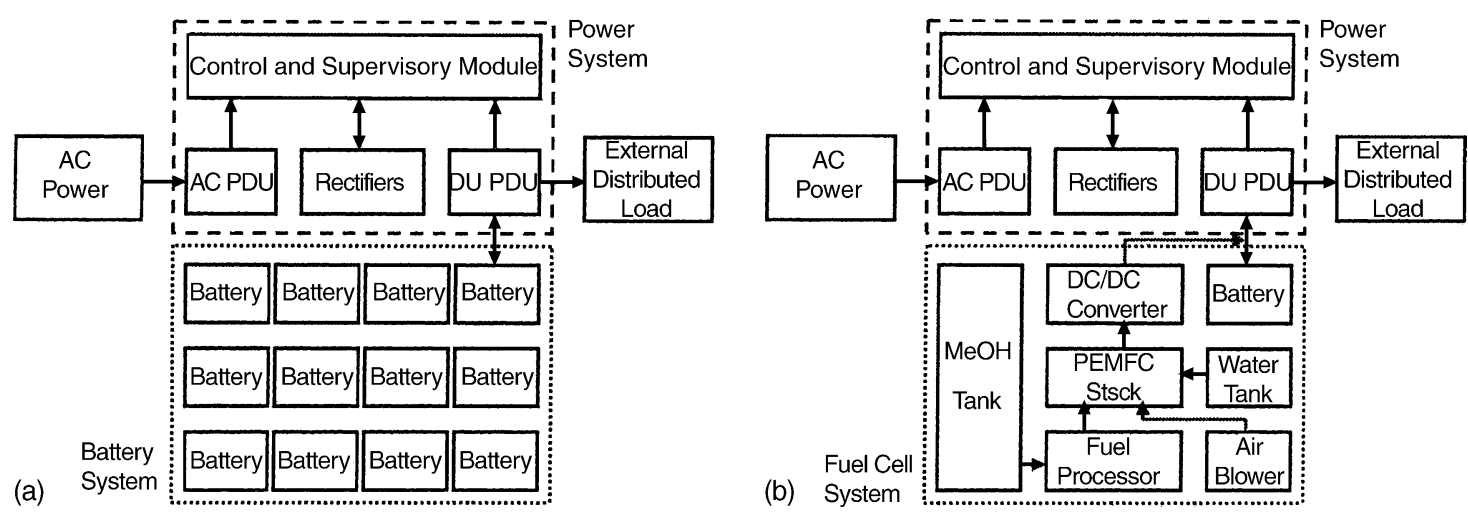

Fig. 1. Simplified schematic diagrams of the energy system used in mobile phone base stations: (a) conventional battery model; (b) fuel cell model.

Table 1

Estimation of the production cost of PEM fuel cell power generating system integrated with methanol reformer and $\mathrm{dc} / \mathrm{dc}$ converter

\begin{tabular}{lrrrr}
\hline & \multicolumn{4}{c}{ Production quantity $\left(\mathrm{pc} \mathrm{year}^{-1}\right)$} \\
\cline { 2 - 5 } & \multicolumn{1}{c}{$1-5$} & \multicolumn{1}{c}{50} & 1,000 & 10,000 \\
\hline 2 kW PEMFC stack (US\$) & 11,642 & 7,463 & 2,985 & 1,493 \\
MeOH reformer (US\$) & 26,866 & 19,403 & 10,448 & 5,970 \\
BOP (US\$) & 7,761 & 5,970 & 3,582 & 2,388 \\
dc/dc converter (US\$) & 358 & 269 & 209 & 149 \\
Total cost (US\$) & 46,627 & 33,105 & 17,224 & 10,000 \\
\hline
\end{tabular}

power generating system fueled by methanol is used instead of the battery system, and the runtime of a base station will depend on the volume of fuel tank.

A typical energy system for the base station can be assumed to have $2 \mathrm{~kW}$ nominal capacity and $2.5 \mathrm{~kW}$ peak capacity. In addition, the runtime of the energy system in the blackout period for this study will be extended from standard $2 \mathrm{~h}$ to $4,8,12$, and $24 \mathrm{~h}$. With the intention to analyse the difference between battery models and fuel cell models, the data corresponding to weight, volume, cost and perfor- mance of each component is collected. Most of the data about power systems and batteries were obtained from Acbel Polytech Inc., and the counterparts about fuel cell systems have been provided by Tatung Company.

Due to the fuel cell system not being a commercially viable product, the production cost absolutely depends on the customer's purchasing quantity. Estimated costs of $2 \mathrm{~kW}$ fuel cell systems for various production quantities are listed in Table 1 . The production cost will be as high as US\$ 46,627 for a small quantity, and reduce to US\$10,000 for 10,000 units. Unlike the case of a large capacity fuel cell system, the reformer seems to be the most expensive component in a $2 \mathrm{~kW}$ system. Also, the costs of small and special BOP components are quite expensive, even more than those of fuel cell stacks in mass production.

\section{Results and discussions}

The calculated results about device cost, module weight, module volume and energy expense of lead-acid battery models for 2, 4, 8, 12, and $24 \mathrm{~h}$ service time are shown in Table 2,

Table 2

Calculated results of device cost, module weight, module volume and energy expense of lead-acid battery systems used in the mobile phone base station

\begin{tabular}{|c|c|c|c|c|c|}
\hline & \multicolumn{5}{|l|}{ Service time } \\
\hline & $2 \mathrm{~h}$ & $4 \mathrm{~h}$ & $8 \mathrm{~h}$ & $12 \mathrm{~h}$ & $24 \mathrm{~h}$ \\
\hline Power system (kg) & 61 & 61 & 61 & 61 & 61 \\
\hline Battery number & $4 \times 1$ & $4 \times 2$ & $4 \times 4$ & $4 \times 6$ & $4 \times 12$ \\
\hline Battery system (kg) & 143 & 286 & 573 & 859 & 1,718 \\
\hline Rack (kg) & 50 & 70 & 100 & 170 & 300 \\
\hline Total weight (kg) & 294 & 417 & 734 & 1,090 & 2,079 \\
\hline Power system (US\$) & 4,600 & 4,600 & 4,600 & 4,600 & 4,600 \\
\hline Battery system (US\$) & 800 & 1,600 & 3,200 & 4,800 & 9,600 \\
\hline Rack (US\$) & 200 & 275 & 350 & 625 & 1,050 \\
\hline Total cost (US\$) & 5,600 & 6,475 & 8,150 & 10,025 & 15,250 \\
\hline Dimension (m) & $0.6 \times 0.6 \times 0.9$ & $0.6 \times 0.6 \times 1.2$ & $0.6 \times 0.6 \times 1.8$ & $0.6 \times 0.6 \times 3.0$ & $0.6 \times 0.6 \times 5.4$ \\
\hline Volume $\left(\mathrm{m}^{3}\right)$ & 0.324 & 0.432 & 0.648 & 1.000 & 1.944 \\
\hline Electricity cost (US\$) & 0.4 & 0.8 & 1.6 & 2.4 & 4.8 \\
\hline
\end{tabular}


Table 3

Calculated results of device cost, module weight, module volume and energy expense of PEM fuel cell systems used in the mobile phone base station

\begin{tabular}{|c|c|c|c|c|c|}
\hline & \multicolumn{5}{|l|}{ Service time } \\
\hline & $2 \mathrm{~h}$ & $4 \mathrm{~h}$ & $8 \mathrm{~h}$ & $12 \mathrm{~h}$ & $24 \mathrm{~h}$ \\
\hline Power system (kg) & 61 & 61 & 61 & 61 & 61 \\
\hline Startup battery (kg) & 111 & 111 & 111 & 111 & 111 \\
\hline Power rack (kg) & 50 & 50 & 50 & 50 & 50 \\
\hline Fuel cell system (kg) & 35 & 35 & 35 & 35 & 35 \\
\hline Fuel and fuel tank (kg) & 2.5 & 5 & 10 & 15 & 30 \\
\hline Fuel cell system case (kg) & 5 & 5 & 5 & 6 & 6 \\
\hline Total weight $(\mathrm{kg})$ & 285 & 287 & 272 & 278 & 293 \\
\hline Power system (US\$) & 4,600 & 4,600 & 4,600 & 4,600 & 4,600 \\
\hline Battery system (US\$) & 520 & 520 & 520 & 520 & 520 \\
\hline Power rack (US\$) & 200 & 200 & 200 & 200 & 200 \\
\hline Fuel cell system (US\$) & 10,000 & 10,000 & 10,000 & 10,000 & 10,000 \\
\hline Total cost (US\$) & 15,320 & 15,320 & 15,320 & 15,320 & 15,320 \\
\hline Dimension/power (m) & $0.6 \times 0.6 \times 0.9$ & $0.6 \times 0.6 \times 0.9$ & $0.6 \times 0.6 \times 0.9$ & $0.6 \times 0.6 \times 0.9$ & $0.6 \times 0.6 \times 0.9$ \\
\hline Dimension/fuel cell (m) & $1.2 \times 1.2 \times 1.0$ & $1.2 \times 1.2 \times 1.0$ & $1.2 \times 1.2 \times 1.0$ & $1.2 \times 1.2 \times 1.0$ & $1.2 \times 1.2 \times 1.0$ \\
\hline Volume/fuel tank (L) & 3 & 6 & 12 & 18 & 36 \\
\hline Total volume $\left(\mathrm{m}^{3}\right)$ & 1.767 & 1.770 & 1.776 & 1.782 & 1.8 \\
\hline Fuel cost (US\$) & 0.5 & 1.0 & 2.0 & 3.0 & 6.0 \\
\hline
\end{tabular}

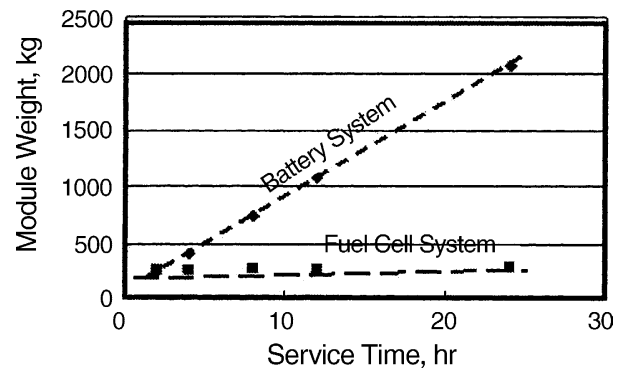

Fig. 2. The variation of module weight of energy systems vs. service time.

and the counterparts for fuel cell models are compiled in Table 3.

As shown in Table 2, the weight of a battery model mainly comes from lead-acid batteries. The total weight of whole energy system is $254 \mathrm{~kg}$ for $2 \mathrm{~h}$ of service time during blackout period, and will rapidly rise to $2079 \mathrm{~kg}$ for $24 \mathrm{~h}$. In the case of the fuel cell model, the startup time of the reformer is approximately $30 \mathrm{~min}$, thus auxiliary batteries should be in-

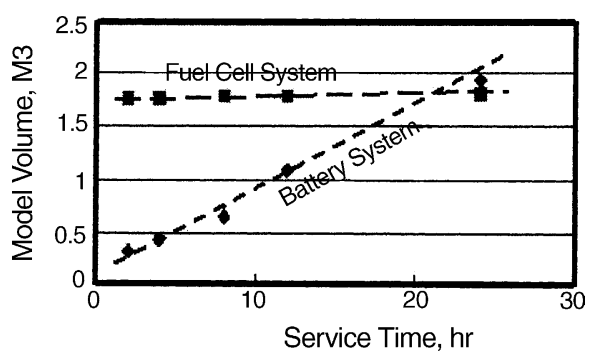

Fig. 3. The variation of module volume of energy systems vs. service time.

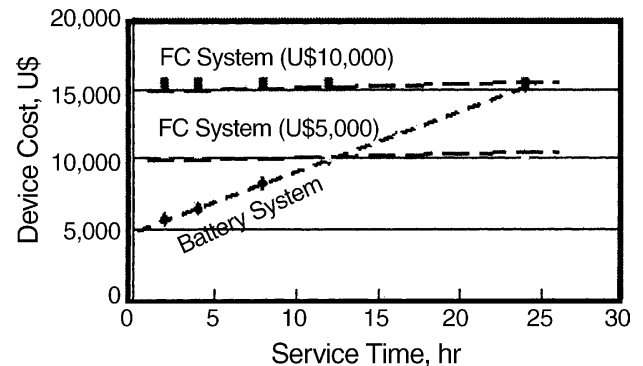

Fig. 4. The variation of device cost of energy systems vs. service time.

stalled to supply electricity before the fuel cell system can take over. As shown in Table 3, the weight of power system, startup batteries and power rack is $222 \mathrm{~kg}$, and the weight of a $2 \mathrm{~kW}$ PEMFC power generating system is $35 \mathrm{~kg}$. Both power and fuel cell systems are the same for various conditions of service time requirements, and only the weight of fuel and fuel tank will be a little different. In Fig. 2, the total weights of two energy systems are compared, and the weight

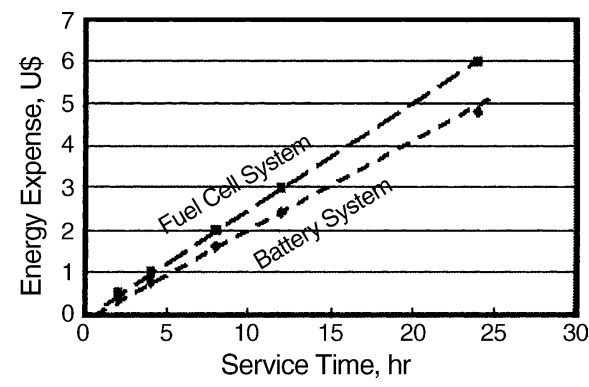

Fig. 5. The variation of energy expense of energy systems vs. service time. 
of a fuel cell model is significantly lower than that of a battery model. The weights are about the same at $2 \mathrm{~h}$ of service time, and the difference becomes larger when the service time increases.

The total volume of a battery model depends on the quantity of batteries, and that of a fuel cell model counts on the fuel cell system. According to this study, the dimensions of a $2 \mathrm{~kW}$ fuel cell system including stack, reformer, inverter and case would be $1.2 \mathrm{~m} \times 1.2 \mathrm{~m} \times 1.0 \mathrm{~m}$, and a GNB $100 \mathrm{AH} / 12 \mathrm{~V}$ battery used in the battery model is only $110 \mathrm{~mm} \times 238 \mathrm{~mm} \times 511 \mathrm{~mm}$. From Fig. 3 , the volume of fuel cell model is obviously bigger than that of battery model, but the difference of total volume will decrease as the service time becomes longer. Note that the total volumes of both systems are approaching the same value when the service time increases to $24 \mathrm{~h}$.

A fuel cell model is currently more expensive than a battery model, but this may not be true for long service time requirement. As shown in Fig. 4, if the service time is $24 \mathrm{~h}$, then the total device costs of both systems are almost the same, and, thereafter, the fuel cell model turns to be cheaper. The better result will be obtained if the cost of the fuel cell system drops from US\$10,000 to 5,000. However, the en- ergy cost of UPS operation is lower in the case of the battery model as depicted in Fig. 5. This result assumes that the electricity price in Taiwan is about US\$ $0.08(\mathrm{kWh})^{-1}$, and the purchasing price of methanol is close to US\$ $0.18 \mathrm{~L}^{-1}$.

\section{Acknowledgements}

This work is supported partly by the Energy R\&D Foundation from the Bureau of Energy, MOEA, and partly by the Funding Program for private companies from the Department of Industrial Technology, MOEA.

\section{References}

[1] "PEM Fuel Cell-UPS for Battery Bank Replacement," Project Opportunity, EPRI, Palo Alto, CA, USA, 2002.

[2] "Fuel Cell: Cost Analysis for Backup Power," Technical Report, Plug Power Inc., Latham, NY, USA.

[3] "Energy System Selection", Technical Brochure, Acbel Polytech Inc., Taipei, Taiwan, 2004.

[4] "Energy Shelf," Cat. No. API2HR25-000, Acbel Polytech Inc., Taipei, Taiwan, 2004. 